3. Мартинсен К. А. Индивидуальная фортепианная техника. Москва : Музыка, 1996. 220 с.

4. Нейгауз Г. Г. Об искусстве фортепианной игры. Записки педагога. Москва : Музыка, 1958. 207 с.

5. Цветаева М. Мать и музыка. URL: http://tsvetaeva.litinfo.ru/tsvetaeva/proza/mat-i-muzyka.htm (date of access 05.11.2020)

DOI https://doi.org/10.30525/978-9934-26-004-9-133

\title{
ІСТОРІЯ СЦЕНІЧНОГО ВТІЛЕННЯ МУЗИЧНО-ТЕАТРАЛЬНИХ ПОСТАНОВОК ЗА МУЗИЧНОЮ П'ССОЮ «ІВАСИК-ТЕЛЕСИК» М. КРОПИВНИЦЬКОГО
}

\author{
Стьопіна А. Ю. \\ аспірантка кафедри інтерпретології та аналізу музики \\ Харківського національного університету мистецтв \\ імені І. П. Котляревського \\ м. Харків, Україна
}

Дитяча музична п’єса «Івасик-Телесик» за мотивами української народної казки видатного українського драматурга, композитора, режисера, одного із засновників Театру українських корифеїв, разом 3 оперою класика української музики Кирила Стеценка - створили не лише фундамент репертуару молодого українського театру для дітей, а й дали основу для подальшого розвитку всієї дитячої драматургії в Україні. В статті зроблено короткий огляд музично-драматичних версій «ІвасикаТелесика» Марка Кропивницького на прикладі музично-драматичних дійств А. Коломійця «Івасик-Телесик», І. Щербакова «Пастка для Відьми», О. Джона Сука «Золотий човник». Відсутність наукових розвідок, які б повно і всебічно висвітлювали сценічні втілення музичної дитячої п’єси М. Кропивницького «Івасик-Телесик» та їх значення для розвитку музичного дитячого театру на Україні, вказує на необхідність більш грунтовного дослідження та актуальність обраної теми.

Ведучи літопис українського дитячого театру ще з його виникнення в дожовтневі часи, ми не можемо обійти ані дитячих п'єс Марка Кропивницького, ані їх сценічного втілення дітьми ще у передреволюційні роки. Однією зі значних, але маловідомих сторін творчої діяльності драматурга було створення дитячої трупи, яка на його думку, могла б стати основою українського дитячого театру. 
Репертуару для театру юного глядача тоді майже не існувало i М. Кропивницький у 1907 році для своїх малих виконавців пише дві п'єси - «васик-Телесик» i «По щучому велінню» за мотивами народних казок. Як відзначає літературознавець Й. Куриленко, ці п’єси «є початок репертуару юного глядача» [3, с. 174]. У виставах були введені вокальні номери, складені Марком Лукичем на теми українських народних мелодій.

Дитяча п'єса-казка «Івасик-Телесик» M. Кропивницькогопрекрасний зразок використання у драматургічної творчості народних пісень, фольклору. Виховний зміст і життєва мудрість п'єси-казки, не складна драматургічна композиція, надзвичайно стислий, розмовний ясний діалог між дійовими особами, прекрасна народна мова, органічно близька до джерел усної поетичної творчості-усе це, як справедливо зауважує М. Йосипенко, $є$ свідченням «серйозного підходу М. Кропивницького до справи написання п'єс для дітей, глибокого знання психології юної аудиторії та іiі культурно-виховних запитів і потреб» [1, с. 265].

Готуючись до постановок своїх дитячих п’єс, Кропивницький написав до них оркестровку. Спочатку, ділиться спогадами письменників син, батько прохав написати музику до «Івасика-Телесика» професійного композитора К. Стеценка, але те, що запропонував цей останній, його не задовольнило - «надто серйозно, але важко для виконання». Водночас свою музику драматург «вважав дещо примітивною, призначеною для виконання, головним чином дітьми» $[2$, с. 140].

Основний сценічний час вистави вимагає участі музики, більше того, відбувається органічне впровадження музики в сам мовний ряд п'єси. Музика роз'яснює і доповнює маленькому глядачеві справжній сенс ситуації. Народні пісні, уведені до драматичної дії, служать засобом самохарактеристики персонажів. Сольні номери, ансамблі, хори органічно вплітаються у драматургічну тканину п'єси.

Дана фабула була застосована класиком української музики К. Стеценком на початку XX століття. Так, у 1910 р. він створив незавершену дитячу оперу-казку на три дії «Івасик-Телесик» за лібрето М. Кропивницького. У 1987 році відомі українські композитори А. Коломієць та В. Кирейко провели значну роботу та здійснили музичну та оркестрову редакції незакінченої опери. Відредагував і завершив твір А. Коломієць у 1962 р. Прем'єра відбулася на сцені Державного дитячого музичного театру (з 2005 р. - Київський муніципальний академічний театр опери і балету для дітей та юнацтва) у 1987 році. Музичний матеріал був частково побудований на інтонаціях та окремих тематичних епізодах класика, але найповніше були використані хорові сцени. Оркестр (диригент-I. Палкін) зумів переконливо, рівно представити трактування усіх музичних образів. 
Ініціатором нової версії на сцені Державного музичного театру для дітей та юнацтва, у якому вона з успіхом ставилася понад десять років, була мистецтвознавець Галина Конькова. Вона створила нове лібрето за літературним першоджерелом М. Кропивницького. 3 епічної історії про страждання хлопчика Івасика в пастці жорстокої відьми спектакль перетворився у розповідь про веселого, життєрадісного хлопчину, що кмітливо обдурює хитру відьму, заманюючи ії в пастку. І. Щербаков зробив вдалу нотно-текстову редакцію опери Кирила Стеценка. Iз матеріалу Стеценка лишилися деякі арії та всі хорові сцени, але було кардинально змінено гармонію, фактуру, загострено рітмику музики, в партитурі з'явилася велика кількість ударних інструментів. Загалом стали помітними риси поп-музики. Самобутня версія відомої казки призвела до появи по суті нової національно визначеної дитячої вистави, в якій не тільки тематичні моменти, але і сценічні образи розвинені на новій жанровій основі.

Вистава насичена вокально-хоровими сценами, яскравим песенними інтонаціями, має вишукану композиторську лексику. В ній органічно поєднані елементи опери-буф, комедії дель'арте 3 традиціями національного музично-драматичного театру i почасти вертепного дійства. Відмінними рисами спектаклю $є$ чіткість і динамізм сюжету, який не вичерпується буквально до останніх тактів твору та добре вибудувана драматургія 3 точно вивіреними кульмінаціями. Музичний матеріал більшості сольних та хорових номерів створено на основі обробок пісенного фольклору. В той же час, не пориваючи 3 народнопісенними традиціями, композитор говорить зі своїми слухачами на мові кінця XX століття.

Протягом XX століття дитяча музична п'єса за мотивом української народної казки «Івасик-Телесик» М. Кропивницького привертала увагу багатьох митців, так М. Сильванський написав Симфонічну казку для читця 3 оркестром «Івасик-Телесик» (1965р.), М. Скорик став автором музики до лялькового анімаційного фільму «Івасик-Телесик» (1968р.), I. Віленський у співавторстві 3 А. Мухою створили балет «ІвасикТелесик» (1971 p.). У XXI сторіччі композитори продовжують створювати музично-сценічні твори на сюжет відомої казки: в репертуарі Харківського академічного театру музичної комедії наявна музична казка «Івасик-Телесик» композитора I. Гайденка (2017-2018pp.), у Одеській національній музичній академії відбулася прем'єра опери для дітей М. Волинського «Івасик-Телесик» (2017р.).

Саме на основі поетичної п'єси «Івасик-телесик» в 2002 році в Першому українському театрі для дітей та юнацтва в м. Львів відбулась прем'єра вистави «Золотий човник» М. Кропивницького в режисурі О. Кравчука. В нього виникла ідея реконструкції п’єси М. Кропив- 
ницького на поєднанні українського стилю та стилю східної культури. Він вирішив інтерпретувати «Івасика Телесика» саме на японському стилі, це був синтез театрів «Но» та «Кабукі». Режисер та автор музики обрали серед класичних сюжетів національної дитячої художньої культури той, що з найбільшою виразністю мог бути переданий за допомогою музики і пластики. Ще одним привідом до створення стилізованої постановки стало переконання режисера тому, що казки всіх країн і символи, якими вони оперують, дуже схожі. Стиль виставі задавала, в першу чергу, авторська музика Олега Джона Сука, котра була мотивом цілої вистави. Специфічна темброво-емоційна палітра вистави складається 3 мелодичної мови акторів i хора, звучання інструментального ансамблю i унікальних «атакуючих вигуків» барабанщика. Організуючим конструктивним початком музиці спектаклю виступає метроритмічний каркас, основа якого - в партії ударних інструментів. Партія флейти трактується автором як мелодичноактивний елемент музичної партитури, тоді як вокальна лінія багато в чому втілює інтонації сценічної мови. Важлива також видовищносимволічна роль у виставі музикантів і хору, коли їх фігури і жести стають необхідним фоном сценічної дії.

Висновки. Марко Лукич Кропивницький своїм творчим спадком i практичною діяльністю зробив свій вклад в історію української музичної дитячої драматургії і українського дитячого театру. На основі аналізу сценічних версій музичної п’єси Кропивницького «Івасик Телесик» доведено актуальність сюжету першоджерела, яке може бути інтерпретоване і успішно використане в сучасних умовах. Обгрунтовано, що музична тканина цих творів $є$ відзеркаленням традицій української музичної культури у поєднанні із новаціями.

\section{Література:}

1. Йосипенко М. К. Марко Лукич Кропивницький. К.: Держвидав, $1958.323 \mathrm{c}$.

2. Кропивницький В. М. Із сімейної хроніки Марка Кропивницького: (Спогади про батька). К.: Мистецтво, 1968. 214 с.

3. Куриленко Я. І. Драматургия Марка Кропивницького и наша современность. Советская Украина: 10, 1960. 172-175 с. 